\title{
MODEL PEMBELAJARAN KOOPERATIF TIPE SCRAMBLE BERBANTUAN BAHAN MANIPULATIF BERPENGARUH TERHADAP KOMPETENSI PENGETAHUAN MATEMATIKA
}

\author{
Ni Luh Novita Deviana \\ Jurusan Pendidikan Guru Sekolah Dasar Universitas Pendidikan Ganesha, \\ E-mail: novidevi51@gmail.com \\ I Wayan Wiarta \\ Jurusan Pendidikan Guru Sekolah Dasar Universitas Pendidikan Ganesha \\ E-mail:wayanwiarta.63@gmail.com \\ Komang Ngurah Wiyasa \\ Jurusan Pendidikan Guru Sekolah Dasar Universitas Pendidikan Ganesha \\ E-mail: komang.wiyasa@yahoo.com
}

\begin{abstract}
Abstrak
Penelitian ini bertujuan untuk mengetahui pengaruh model pembelajaran kooperatif tipe scramble berbantuan bahan manipulatif terhadap kompetensi pengetahauan matematika siswa kelas IV SD Gugus Letkol Wisnu Denpasar Utara Tahun Pelajaran 2016/2017. Jenis penelitian ini merupakan eksperimen semu dengan desain penelitian kelompok non-ekuivalen. Populasi penelitian ini adalah seluruh siswa kelas IV SD Gugus Letkol Wisnu Denpasar Utara Tahun Pelajaran 2016/2017 yang banyaknya 344 siswa. Sampel ditentukan dengan random sampling dengan mengacak kelas. Sampel dalam penelitian ini adalah kelas IV SD Negeri 1 Peguyangan sebagai kelompok eksperimen dan kelas IV SD Negeri 3 Peguyangan sebagai kelompok kontrol dengan jumlah masing-masing kelompok sebanyak 45 siswa pada kelompok ekperimen dan 48 siswa pada kelompok kontrol. Data kompetensi pengetahuan matematika dikumpulkan dengan instrumen berupa tes objektif berjumlah 20 butir tes yang telah divalidasi. Data kompetensi pengetahuan matematika dianalisis dengan t-test. Berdasarkan hasil analisis diperoleh thitung $=7,27$ dan $t_{\text {tabel }(\alpha=0,05,91)}=1,980$ ( $t_{\text {hitung }}>t_{\text {tabel }}$ ), sehingga Ho ditolakdan Ha diterima, yang berarti terdapat perbedaan yang signifikan kompetensi pengetahuan matematika kelompok siswa yang dibelajarkan menggunakan model pembelajaran kooperatif tipe scramble berbantuan bahan manipulatif dan kelompok siswa yang tidak dibelajarkan menggunakan model pembelajaran kooperatif tipe scramble berbantuan bahan manipulatif pada siswa kelas IV SD Gugus Letkol Wisnu Denpasar Utara Tahun Pelajaran 2016/2017. Nilai rata-rata kompetensi pengetahuan matematika siswa kelompok eskperimen lebih dari rata-rata kompetensi pengetahuan matematika siswa kelompok kontrol $(\bar{X}=78,39>\bar{X}=60)$. Sehingga dapat disimpulkan bahwa penerapan model pembelajaran kooperatif tipe scramble berbantuan bahan manipulatif berpengaruh terhadap kompetensi pengetahuan matematika siswa kelas IV SD Gugus Letkol Wisnu Denpasar Utara Tahun Pelajaran 2016/2017.
\end{abstract}

Kata-kata kunci : scramble, bahan manipulatif, kompetensi pengetahuan matematika.

\begin{abstract}
The research aimed to determine the impact of cooperative learning model type scramble assisted manipulative materials on mathematics knowledge competency in fourth grade at SD Gugus Letkol Wisnu Denpasar Utara academic year 2016/2017. This type of research was a quasi-experimental research using non-equivalent control group design. The population of this research is all student in fourth grade at SD Gugus Letkol Wisnu Denpasar Utara academic year 2016/2017 which 344 students. The samples were taken with a random sampling technique to randomize the class. The sample in this study is in fourth grade of SD Negeri 1 Peguyangan as the experimental group and in fourth grade of SD Negeri 3 Peguyangan as a control group, which each group as many as 45 students in the experimental group and 48 students in the control group. The data of mathematics knowledge competency were collected by instruments in the form of objective test, which amounts to 20 items that have been validated. The data of mathematics knowledge competency were analyzed by $t$ - test. Based on the results of the analysis obtained $t_{\text {count }}=7,27$ and $t_{\text {table }}(\alpha=0,05,91)=1,980\left(t_{\text {count }}>t_{\text {table }}\right)$, so Ho rejected and Ha accepted, it means there is a significant differences in the mathematics knowledge competency of the group that learned by cooperative learning model type scramble assisted manipulative materials and the group who are not learned by cooperative learning model type scramble assisted manipulative materials in fourth grade at SD Gugus Letkol Wisnu Denpasar Utara academic year 2016/2017. The average value of mathematics knowledge competency in the experimental group is more than average of mathematics knowledge competency in the control group $(\bar{X}=78,39>\bar{X}=$ 60 ). So, it can be concluded that the application of cooperative learning model type scramble assisted manipulative materials had an effect on mathematics knowledge competency in fourth grade at SD Gugus Letkol Wisnu Denpasar Utara academic year 2016/2017.
\end{abstract}

Keywords: scramble, manipulative materials, and mathematics knowledge competency 


\section{Pendahuluan}

Pendidikan merupakan kebutuhan yang sangat penting yang berfungsi untuk meningkatkan mutu kehidupan manusia. Pendidikan juga berperan penting dalam mempersiapkan dan mengembangkan sumber daya manusia yang handal dan mampu bersaing secara sehat sebagaimana tujuan pendidikan itu sendiri. Oleh karena itu, setiap orang berhak mendapatkan pendidikan yang layak.

Pendidikan adalah usaha sadar dan terencana untuk mewujudkan suasana belajar dan proses pembelajaran agar peserta didik secara aktif mengembangkan potensi dirinya untuk memiliki kekuatan spiritual keagamaan, pengendalian diri, kepribadian, kecerdasan, akhlak mulia, serta keterampilan yang diperlukan dirinya, masyarakat, bangsa dan negara (Undang - Undang No. 20 Tahun 2003 tentang Sistem Pendidikan Nasional). Kurikulum merupakan salah satu indikator di dalam menentukan keberhasilan suatu pendidikan.

Kurikulum adalah pengaturan mengenai tujuan, isi, dan bahan pelajaran serta cara yang digunakan sebagai pedoman penyelenggaraan kegiatan pembelajaran untuk mencapai tujuan pendidikan tertentu (UU No. 20 Tahun 2003 tentang Sistem Pendidikan Nasional). Kurikulum pada Sekolah Dasar/Madrasah Ibtidaiyah yang telah dilaksanakan sejak tahun ajaran 2013/2014 disebut Kurikulum 2013 Sekolah Dasar/Madrasah Ibtidaiyah (Permendikbud Nomor 57 tahun 2014 lampiran 1). Kurikulum 2013 bertujuan untuk mempersiapkan manusia Indonesia agar memiliki kemampuan hidup sebagai pribadi dan warga negara yang beriman, produktif, kreatif, inovatif, dan afektif serta mampu berkontribusi pada kehidupan bermasyarakat, berbangsa, bernegara, dan peradaban dunia (Permendikbud No. 57 tahun 2014 lampiran I).

Proses pembelajaran pada Kurikulum 2013 untuk semua jenjang dilaksanakan dengan menggunakan pendekatan saintifik. Pendekatan saintifik adalah pendekatan saintifik adalah suatu pendekatan pembelajaran yang mengutamakan temuan siswa sehingga siswa secara kreatif dan aktif mengonstruk konsep, prinsip, melalui peristiwa mengamati, menanya, mengumpulkan informasi/melakukan eksperimen, mengasosiasikan/mengolah informasi, dan mengkomunikasikan.

Penerapan kurikulum 2013 diharapkan mampu meningkatkan kompetensi pengetahuan matematika peserta didik, sehingga tujuan pembelajaran matematika dapat tercapai.

Japa dan Suarjana (2014:3) menyatakan tujuan dibelajarkannya matematika di sekolah dasar adalah agar peserta didik memiliki kemampuan : (1) memahami konsep matematika, mengetahui keterkaitan antar konsep dan mampu mengaplikasikan konsep atau algoritma matematika itu secara luwes, akurat, efisien, dan tepat dalam pemecahan masalah. (2) menggunakan penalaran pada pola dan sifat, melakukan manipulasi matematika dalam membuat generalisasi, menyusun bukti atau menjelaskan gagasan dan pernyataanpernyataan matematika. (3) memecahkan masalah yang meliputi kemampuan memahami masalah, merancang model matematika, menyelesaikan model dan menafsirkan/menginterpretasikan solusi yang diperoleh. (4) mengkomunikasikan gagasan dengan simbol, tabel, diagram, atau media lain untuk memperjelas keadaan atau masalah. (5) memiliki sikap menghargai kegunaan matematika dalam kehidupan yaitu memiliki rasa ingin tahu, perhatian dan minat dalam mempelajari matematika serta sikap ulet dan percaya diri dalam pemecahan masalah.

Berdasarkan observasi yang telah dilakukan pada tanggal 19 Januari 2017 di seleruh sekolah dasar yang berada di Gugus Letkol Wisnu Denpasar Utara diperoleh hasil nilai ulangan akhir semester 1 pada muatan materi matematika, yaitu dari 344 siswa kelas IV, 2 siswa yang mendapat nilai A-, 8 siswa yang mendapat nilai $\mathrm{B}+, 9$ siswa yang mendapat nilai $\mathrm{B}, 20$ siswa yang mendapat nilai $\mathrm{B}-, 25$ siswa yang mendapat nilai $\mathrm{C}+$, 34 siswa yang mendapat nilai C, 66 siswa yang mendapat nilai C-, 64 siswa yang mendapat nilai D+, 116 siswa yang mendapat nilai D. Kriteria Ketuntasan Minumum (KKM) untuk kompetensi pengetahuan yang diharapkan oleh SD di seluruh Gugus Letkol Wisnu rata-rata adalah B-. Jadi dari data tersebut sebanyak 39 siswa yang sudah mencapai KKM, sedangkan 305 siswa yang belum mencapai KKM. Ini memperlihatkan bahwa $89 \%$ siswa memiliki kompetensi pengetahuan matematika yang berada dibawah KKM dan hanya $11 \%$ yang mampu mencapai KKM.

Hal ini menunjukkan kompetensi pengetahuan matematika belum sesuai dengan tujuan kurikulum 2013. Banyak faktor yang melatarbelakangi hal tersebut, diantaranya kurangnya keaktifan siswa dalam pembelajaran matematika dan penggunaan model pembelajaran yang tidak sesuai dengan karakteristik siswa SD serta bersifat konvensional. Selain itu menurut Muhsetyo (2008:1.2) "ciri keabstrakan matematika beserta ciri lainnya yang tidak sederhana, menyebabkan matematika tidak mudah untuk dipelajari, dan pada akhirnya banyak siswa yang kurang tertarik terhadap matematika".

Masalah tersebut dapat diselesaikan guru dengan cara menciptakan suasana belajar yang menyenangkan, mendesain pembelajaran yang kreatif dan inovatif dengan memperhatikan karakteristik perkembangan siswa. Inovasi pembelajaran yang dapat dilakukan untuk menyelesaikan masalah tersebut adalah dengan menerapkan model pembelajaran kooperatif tipe scramble berbantuan bahan manipulatif. Berdasarkan hasil wawancara pada tanggal 19 Januari 2017, model ini belum pernah diterapkan dalam proses pembelajaran. 
Metode scramble menurut Rober B. Taylor (dalam Huda, 2013:303) merupakan "salah satu metode pembelajaran yang dapat meningkatkan konsentrasi dan kecepatan berpikir siswa". "Dalam metode ini, mereka tidak hanya diminta untuk menjawab soal, tetapi juga menerka dengan cepat jawaban soal yang sudah tersedia namun masih dalam kondisi acak" (Huda, 2013:303-304). Model pembelajaran kooperatif tipe scramble adalah model pembelajaran yang menugaskan siswa untuk menjawab pertanyaan yang sudah menyediakan jawaban namun dengan susunan yang acak dengan cara mengkoreksi jawaban tersebut sehingga menjadi jawaban yang benar (Kurniasih dan Sani, 2016). Jadi dapat dirangkum bahwa model pembelajaran kooperatif tipe scramble adalah model pembelajaran yang melibatkan partisipasi siswa dalam satu kelompok kecil untuk menjawab pertanyaan yang sudah menyediakan jawaban namun dengan susunan yang acak dengan cara mengkoreksi jawaban tersebut sehingga menjadi jawaban yang benar.

Model pembelajaran kooperatif tipe scramble dapat digunakan untuk meningkatkan keaktifan belajar siswa, meningkatkan motivasi serta timbul minat belajar siswa terhadap pelajaran matematika. Secara tidak langsung model ini akan menumbuhkan ketertarikan siswa terhadap pelajaran matematika dan pada akhirnya diharapkan dapat pula meningkatkan kompetensi pengetahuan matematika siswa.

Untuk memudahkan siswa dalam memahami suatu konsep, siswa dapat menggunakan bantuan media berupa bahan manipulatif. Teori belajar Bruner menyatakan bahwa "untuk memberikan pemahaman kepada siswa tentang suatu materi/konsep matematika dalam proses pembelajaran, mereka sebaiknya diberi kesempatan memanipulasi benda-benda atau alat peraga yang dirancang secara khusus dan dapat diutak-atik atau dimanipulasi" (Japa, 2014: 8). Bahan manipulatif dalam pembelajaran matematika SD adalah "alat bantu pembelajaran yang digunakan terutama untuk menjelaskan konsep dan prosedur matematika. Alat ini merupakan bagian langsung dari matematika dan dapat dimanipulasi oleh peserta didik (dibalik, dipotong, digeser, dipindah, digambar ditambah, dipilah, dikelompokan /diklarifikasikan)" (Muhsetyo, 2008: 2.1). Berdasarkan beberapa teori tersebut, dapat dirangkum, bahan manipulatif adalah bahan yang dapat dimanipulasikan atau dimain-mainkan dengan tangan untuk menanamkan konsep matematika tertentu. Penggunaan bahan manipulatif dalam proses pembelajaran berfungsi untuk menyederhanakan konsep yang abstrak, menyajikan bahan yang relatif abstrak menjadi lebih nyata, menjelaskan pengertian atau konsep secara lebih konkret.

Pembelajaran dengan model pembelajaran kooperatif tipe scramble jika dipadukan dengan berbagai bahan manipulatif akan membantu proses pemecahan masalah yang dilakukan siswa. Keduanya sama-sama mampu meningkatkan keaktifan siswa, memberikan pemahaman yang bermakna kepada siswa sehingga tidak cepat dilupakan siswa, dan memberikan pengaruh positif terhadap kompetensi pengetahuan matematika.

Berdasarkan latar belakang yang telah diuraikan dilakukan penelitian yang berjudul "Pengaruh Model Pembelajaran Kooperatif Tipe Scramble Berbantuan Bahan Manipulatif terhadap Kompetensi Pengetahuan Matematika Siswa Kelas IV SD Gugus Letkol Wisnu Denpasar Utara Tahun Pelajaran 2016/2017'. Tujuan yang ingin dicapai dari penelitian ini adalah untuk mengetahui kompetensi pengetahuan matematika siswa yang dibelajarkan menggunakan model pembelajaran kooperatif tipe scramble berbantuan bahan manipulatif dan kompetensi pengetahuan matematika siswa yang tidak dibelajarkan menggunakan model pembelajaran kooperatif tipe scramble berbantuan bahan manipulatif, serta untuk mengetahui pengaruh model pembelajaran kooperatif tipe scramble berbantuan bahan manipulatif terhadap kompetensi pengetahuan matematika siswa kelas IV SD Gugus Letkol Wisnu Denpasar Utara Tahun Pelajaran 2016/2017.

\section{Metode Penelitian}

Penelitian ini dilaksanakan pada bulan Desember 2016 sampai dengan bulan Mei 2017 di kelas IV SD Gugus Letkol Wisnu Kecamatan Denpasar Utara. Jenis penelitian yang dilakukan dalam penelitian ini adalah penelitian kuantitatif dengan desain eksperimental yaitu quasi eksperiment (eksperimen Semu). "Desain ini memiliki kelompok kontrol, tetapi tidak bisa sepenuhnya mengontrol variabel-variabel luar yang mempengaruhi pelaksanaan eksperimen" (Sugiyono, 2014:114). Desain eksperimen yang digunakan adalah "Kelompok Non-ekuivalen". Pre-test diberikan untuk kelompok kontrol dan kelompok eksperimen. Pemberian pre test biasanya digunakan untuk mengukur equivalensi atau penyetaraan kelompok. Setelah itu diberikan perlakuan, yaitu dengan memberikan model pembelajaran kooperatif tipe scramble berbantuan bahan manipulatif kepada kelompok eksperimen. Kemudian setelah diberikan perlakuan, dilakukan post-test untuk mengetahui kompetensi pengetahuan matematika.

"Populasi adalah kumpulan dari individu dengan kualitas serta ciri-ciri yang telah ditetapkan" (Nazir, 2011:271). Menurut Sugiyono (2014:117) “populasi adalah wilayah generalisasi yang terdiri atas obyek atau subyek yang mempunyai kualitas dan karakteristik tertentu yang ditetapkan untuk dipelajari dan kemudian ditarik kesimpulannya". Jadi, populasi adalah kumpulan dari orang yang memiliki karakteristik tertentu yang menjadi sumber pengambilan sampel yang ingin diteliti lalu dipelajari dan ditarik simpulan. Populasi dari penelitian ini adalah seluruh siswa kelas IV (empat) SD Gugus Letkol wisnu Denpasar Utara yang berjumlah 344 siswa, yang terdiri dari 9 kelas dalam 7 sekolah dasar. Berdasarkan hasil wawancara yang diperoleh dari 
kepala sekolah serta guru kelas IV di masing-masing SD Gugus Letkol wisnu yaitu bahwa kelas IV dari tujuh sekolah yang ada di Gugus Letkol wisnu setara secara akademik yang memiliki nilai rata-rata tidak jauh berbeda. Dikatakan setara, karena pengelompokan siswa ke dalam kelas-kelas dari 7 sekolah yang ada disebar secara merata antara siswa yang memiliki kemampuan tinggi, sedang, dan rendah. Dengan demikian tidak terdapat kelas unggulan maupun non unggulan.

"Sampel adalah sekelompok objek, orang, peristiwa, dan sebagainya yang merupakan representasi dari keseluruhan" (Setyosari, 2015:220). Penggunaan sampel bertujuan untuk menghemat waktu, tenaga, dan biaya dalam melakukan penelitian. Teknik pengambilan sampel pada penelitian ini adalah random sampling dan yang dirandom adalah kelasnya, sehingga setiap kelas mendapatkan peluang yang sama untuk menjadi sampel penelitian. Dari 9 kelas yang ada di Gugus Letkol Wisnu, dilakukan dua kali pengundian. Pengundian pertama dilakukan untuk memilih dua kelas yang dijadikan sampel penelitian. Berdasarkan pengundian pertama yang dilakukan diperoleh 2 kelas yang akan dijadikan sampel penilitian, yaitu kelas IVA SD Negeri 1 Peguyangan yang berjumlah 45 siswa dan kelas IV SD Negeri 3 Peguyangan yang berjumlah 48 siswa. Untuk mendapatkan kelas yang setara dari segi akademik, maka kedua kelas yang menjadi sampel penelitian kemudian diberikan pre-test. Nilai atau skor dari hasil pre-test yang dilakukan tersebut, digunakan untuk penyetaraan kelas. Untuk penyetaraan kelas, nilai atau skor dari hasil pre-test seluruh populasi dianalisis menggunakan uji-t. Sebelum uji kesetaraan menggunakan uji-t, maka data hasil pre test diuji prasyarat yaitu normalitas dan homogenitasnya. Jika data pre test yang diperoleh sudah memenuhi prasyarat uji normalitas dan homogenitas barulah dianalisi menggunakan uji-t. Setelah kedua kelas yang menjadi sampel diketahui setara secara akademik, maka dilakukan pengundian kedua untuk menentukan kelompok eksperimen dan kelompok kontrol.

Berdasarkan perhitungan hasil uji normalitas sebaran data nilai pre-test Kelas IVA SDN 1 Peguyangan $\mathrm{X}^{2}{ }_{\text {hitung }}=5,037$ dan $\mathrm{X}_{\text {tabel }}^{2}=11,07$, karena $\mathrm{X}^{2}{ }_{\text {hitung }}<\mathrm{X}^{2}$ tabel maka data berdistribusi normal. Sedangkan perhitungan hasil uji normalitas nilai pre-test Kelas IV SDN 3 Peguyangan diperoleh $\mathrm{X}^{2}$ hitung $=1,353$ dan $\mathrm{X}_{\text {tabel }}^{2}$ $=11,07$. Karena $\mathrm{X}^{2}$ hitung $<\mathrm{X}_{\text {tabel }}^{2}$ maka data berdistribusi normal.

Setelah uji normalitas dilakukan diperoleh kedua kelas sampel bersistribusi normal, maka uji homogenitas dapat dilakukan. Uji homogenitas varian data hasil pre-test kompetensi pengetahuan matematika siswa dilakukan dengan menggunakan uji $\mathrm{F}$. Berdasarkan hasil uji homogenitas varians $\mathrm{F}_{\text {hitung }}=1,27$ dan $\mathrm{F}_{\text {tabel }}=1,6$, karena $\mathrm{F}_{\text {hitung }}<\mathrm{F}_{\text {tabel }}$ maka data homogen.

Karena data nilai pre-test kedua kelas sampel berdistribusi normal dan homogen, maka dilanjutkan dengan melakukan uji kesetaraan dengan uji-t. Berdasarkan hasil analisis didapat $t_{\text {hitung }}=1,03$ dan $t_{\text {tabel }}$ pada taraf signifikan 5\% dengan derajat kebebasan $\mathrm{dk}=\left(\mathrm{n}_{1}+\mathrm{n}_{2}-2\right)=1,980$. Sehingga $\mathrm{t}_{\text {hitung }}<\mathrm{t}_{\text {tabel }}(1,61<1,980)$. Berdasarkan uji-t kesetaraan yang telah dilakukan diperoleh bahwa kedua kelas tersebut setara. Setelah diketahui kedua kelompok sampel setara, kemudian dilakukan pengundian yang kedua untuk menentukan kelas ekperimen dan kelas kontrol. Setelah dilakukan random maka kelas yang terpilih untuk menjadi kelompok eksperimen adalah kelas IVA di SD Negeri 1 Peguyangan. Untuk kelas kontrol terpilih kelas IV di SD Negeri 3 Peguyangan.

Metode pengumpulan data yang digunakan dalam penelitian ini adalah dengan metode tes. Menurut Suharsimi (2013:67) "tes adalah alat atau prosedur yang digunakan untuk mengetahui atau mengukur sesuatu dalam suasana, dengan cara dan aturan-aturan yang sudah ditentukan". Menurut Sudijono (2013:67) "tes adalah cara atau prosedur dalam rangka pengukuran dan penilaian di bidang pendidikan, yang berupa pertanyaan-pertanyaan yang harus dijawab oleh testee, sehingga dapat dihasilkan nilai yang melambangkan tingkah laku atau prestasi testee yang dapat dibandingkan dengan nilai standar tertentu". Berdasarkan pendapat tersebut dapat dirangkum bahwa tes adalah deretan pertanyaan yang digunakan untuk proses pengukuran atau alat ukur dalam pembelajaran untuk pemberian angka dengan membandingkan alat ukur/satuan ukur yang digunakan. Tes yang digunakan untuk mengukur kompetensi pengetahuan matematika pada penelitian ini berupa tes objektif dalam bentuk pilihan ganda biasa. Tes pilihan ganda biasa ini meliputi 4 pilihan jawaban (a, b, c atau d) dengan jumlah pertanyaan yaitu 35 butir soal. Setiap item diberikan skor 1 bila siswa menjawab dengan benar (jawaban disesuaikan dengan kunci jawaban) dan skor 0 bila siswa menjawab salah. Skor setiap jawaban dijumlahkan dan jumlah tersebut menjadi skor variabel kompetensi pengetahuan matematika yang bergerak dari kisaran 0-35. 0 merupakan skor minimal dan 35 merupakan skor maksimal ideal tes kompetensi pengetahuan matematika. Sebelum tes ini digunakan dilakukan pengujian instrumen yaitu uji validitas, daya beda, indeks kesukaran dan reliabilitas.

Uji validitas isi dalam penelitian ini adalah kurikulum dan kisi-kisi. Untuk mengukur validitas butir tes kompetensi pengetahuan matematika dalam bentuk objektif pilihan ganda digunakan rumus koofesien korelasi point biserial $\left(\mathrm{r}_{\mathrm{pbi}}\right)$. Nilai yang diperoleh kemudian dibandingkan dengan nilai yang diperoleh dari $\mathrm{r}$ tabel, jika r hitung > r tabel maka dalam katagori valid. Dari hasil perhitungan dengan $r$ tabel pada taraf signifikansi 0,05 yaitu 0,2973 terdapat 15 soal yang kurang dari $r$ tabel $(0,2973)$ dan 20 butir soal yang lebih dari $r$ tabel $(0,2973)$. 20 butir soal yang sudah valid kemudian dilakukan pengujian daya beda. Dari analisis uji daya beda diketahui 1 butir soal dengan kriteria sangat baik, 16 butir soal dengan kriteria baik, dan 3 butir soal dengan kriteria 
cukup baik. Soal yang baik adalah soal yang tidak terlalu mudah atau tidak terlalu sukar. Hal ini didukung oleh pendapat Yusuf (2015:254-255 ) yang menyatakan "item yang terlalu mudah atau item yang terlalu sukar merupakan hal yang tidak baik"). Sesuai dengan kriteria penilaian yang ditentukan maka diperoleh tingkat kesukaran butir tes yaitu butir soal dengan kriteria mudah 5 soal, butir soal dengan kriteria sedang 10 soal, dan 5 butir soal dengan kriteria sukar. Untuk tingkat kesukaran perangkat tes yaitu 0,573 dengan kategori sedang. Pengujian instrument yang terakhir adalah uji reliabilitas. Uji reliabilitas dilakukan terhadap butir soal yang valid saja. Uji reliabilitas tes yang bersifat dikotomi dan heterogen ditentukan dengan rumus Kuder Richadson (KR-20). Berdasarkan hasil analisis reliabilitas diperoleh $r_{11}=0,83$ yang berarti tes ini memiliki reliabiliatas sangat tinggi.

Data kompetensi pengetahuan matematika adalah data hasi dari post-test yang diberikan setelah perlakuan. Data tersebut kemudian dianalisis dengan metode analisis statistik. Metode analisis statistik dapat dibagi menjadi dua, yaitu statistik deskriptif dan statistik inferensial. Stastistik deskriptif menurut Sugiyono (2014:207-208) adalah "statistik yang digunakan untuk menganalisis data dengan cara mendeskripsikan atau menggambarkan data yang telah terkumpul sebagaimana adanya tanpa bermaksud membuat kesimpulan yang berlaku untuk umum atau generalisasi”. Adapun data yang disajikan dalam statistik deskriptif adalah perhitungan mean, standar deviasi dan varians.

"Statistik inferensial adalah teknik statistik yang digunakan untuk menganalisis data sampel dan hasilnya diberlakukan untuk populasi" (Sugiyono, 2014:209). Statistik inferensial teridiri dari pengujian prasyarat analisis dan pengujian hipotesis. Sebelum dilakukan uji hipotesis, terlebih dahulu dilakukan uji prasyarat analisis data. Uji prasyarat yang dilakukan dalam penelitian ini adalah uji normalitas dan homogenitas. Uji Normalitas dimaksudkan untuk mengetahui apakah sebaran data skor kompetensi pengetahuan matematika siswa masing-masing kelompok berdistribusi normal atau tidak sehingga dapat menentukan teknik analisis datanya. Uji Normalitas sebaran data dalam penelitian ini menggunakan Chikuadrat. Kriteria pengujian adalah jika $X_{H i t}^{2}<X_{\text {tabel }}^{2}$, maka $\mathrm{h}_{\mathrm{o}}$ diterima (gagal ditolak) yang berarti data berdistribusi normal. Sedangkan taraf signifikansinya adalah $5 \%$ dan derajat kebebasannya $\mathrm{n}-1$. Uji Homogenitas dilakukan untuk menunjukkan bahwa perbedaan yang terjadi pada uji hipotesis benar-benar terjadi akibat adanya perbedaan varians antar kelompok, bukan sebagai akibat perbedaan dalam kelompok. Uji homogenitas dapat dilakukan apabila kelompok data tersebut berdistribusi normal. Uji homogenitas varians dilakukan dengan uji F. Kriteria pengujian, jika $F_{\text {hit }}<F_{\text {tabel }}$ maka sampel homogen. Analisis data dalam penelitian ini menggunakan uji beda mean (uji t) dengan rumus polled varians. Dengan kriteria jika harga thitung $\leq \mathrm{t}_{\text {tabel}}$, maka Ho diterima dan Ha ditolak, dan jika harga $\mathrm{t}_{\text {hitung }}>\mathrm{t}_{\text {tabel }}$ maka Ho ditolak dan Ha diterima. Pada taraf signifikan $5 \%$ dengan $\mathrm{dk}=\mathrm{n} 1+\mathrm{n} 2-2$.

\section{Hasil dan Pembahasan}

Berdasarkan hasil analisis statistik deskriptif kompetensi pengetahuan matematika kelompok eksperimen diperoleh $\mathrm{X}^{-}=78,39$ dan rerata persentase kompetensi pengetahuan matematika kelompok eksperimen 78,39\%. Rerata persentase kompetensi pengetahuan matematika tersebut kemudian dikonversikan pada tabel PAP skala lima, sehingga dapat diketahui kompetensi pengetahuan matematika siswa kelompok eksperimen berada pada kategori cukup.

Sedangkan hasil analisis statistik deskriptif kompetensi pengetahuan matematika kelompok kontrol diperoleh $\bar{X}=60$ dan rerata persentase kompetensi pengetahuan matematika kelompok kontrol adalah $60 \%$. Rerata persentase kompetensi pengetahuan matematika tersebut kemudian dikonversikan pada tabel PAP skala lima, sehingga dapat diketahui kompetensi pengetahuan matematika siswa kelompok kontrol berada pada kategori kurang. Sesuai dengan hasil analisis data kompetensi pengetahuan matematika menunjukkan bahwa rata-rata kompetensi pengetahuan matematika siswa kelompok eskperimen lebih dari rata-rata kompetensi pengetahuan matematika siswa kelompok kontrol $(\bar{X}=78,39>\bar{X}=60)$.

Berdasarkan hasil uji normalitas kelompok eksperimen $X^{2}{ }_{\text {hitung }}<X_{\text {tabel }}{ }(5,61<11,07)$ maka $\mathrm{H}_{\mathrm{o}}$ diterima (gagal ditolak) atau $\mathrm{H}_{\mathrm{a}}$ ditolak. Ini berarti sebaran data kompetensi pengetahuan matematika kelompok eksperimen berdistribusi normal. Sedangkan, hasil uji normalitas kelompok kontrol diperoleh $X^{2}{ }_{\text {hitung }}<X_{\text {tabel }}^{2}$ $(2,55<11,07)$ maka $H_{o}$ diterima atau $H_{a}$ ditolak. Ini berarti sebaran data kompetensi pengetahuan matematika kelompok kontrol berdistribusi normal.

Setelah data dinyatakan normal selanjutnya dilakukan pengujian homogenitas dan diperoleh $\mathrm{F}_{\text {hit }}=1,13$, sedangkan untuk taraf signifikan 5\% F tabel dengan dk $(44,47)$ adalah 1,61 . Ini berarti Fhit < Ftabel $(1,01<$ $1,61)$, maka data homogen. Berdasarkan hasil uji normalitas dan homogenitas dapat diketahui bahwa data yang diperoleh dari kelompok eksperimen dan kelompok kontrol berdistribusi normal dan memiliki varians yang homogen. Karena data yang diperoleh telah memenuhi semua prasyarat, uji hipotesis dapat dilakukan dengan menggunakan analisis uji-t dengan rumus polled varians. Adapun kriteria pengujiannya adalah apabila $t_{\text {hitung }} \leq$ 
$t_{\text {tabel}}$, maka $H_{o}$ diterima (gagal ditolak) dan $H_{a}$ ditolak. Sebaliknya apabila $t_{\text {hitung }}>t_{\text {tabel }}$, maka $\mathrm{H}_{\mathrm{o}}$ ditolak dan $\mathrm{H}_{\mathrm{a}}$ diterima. Dengan $\mathrm{dk}=\mathrm{n}_{1}+\mathrm{n}_{2}-2$ dan taraf signifikansi 5\% $(\alpha=0,05)$. Hasil uji $\mathrm{t}$ dapat dilihat pada tabel 1 .

Tabel 1. Rekapitulasi Analisis Uji-t

\begin{tabular}{lllllll}
\hline \multicolumn{1}{c}{ Kelompok } & \multicolumn{1}{c}{$\overline{\mathbf{x}}$} & \multicolumn{1}{c}{$\mathrm{s}^{2}$} & $\mathrm{~N}$ & $\mathrm{t}_{\text {hitung }}$ & $\mathrm{t}_{\text {tabel }}$ & \multicolumn{1}{c}{ Kesimpulan } \\
\hline Eksperimen & 78,39 & 149,04 & 45 & \multirow{2}{*}{7,27} & \multirow{2}{*}{1,980} & $\mathrm{t}_{\text {hitung }}>\mathrm{t}_{\text {tabel }}$ \\
Kontrol & 60 & 147,33 & 48 & & & $\left(\mathrm{H}_{0}\right.$ ditolak, $\mathrm{H}_{\mathrm{a}}$ diterima $)$ \\
\hline
\end{tabular}

Hasil analisis uji $\mathrm{t}$ diperoleh $\mathrm{t}_{\text {hitung }}=7,27$. Harga tersebut kemudian dibandingkan dengan harga $\mathrm{t}_{\text {tabel }}$ dengan $\mathrm{dk}=45+48-2=91$ dan taraf signifikansi $5 \%$ sehingga3 diperoleh harga $t_{\text {tabel }}=1,980$, karena $t_{\text {hitung }}>t_{\text {tabel }}$ maka Ho ditolak atau Ha diterima. Hal ini berarti terdapat perbedaan yang signifikan kompetensi pengetahuan matematika siswa kelompok eksperimen dan siswa kelompok kontrol.

Rata-rata kompetensi pengetahuan matematika siswa kelompok eskperimen lebih dari rata-rata kompetensi pengetahuan matematika siswa kelompok kontrol $(\bar{X}=78,39>\bar{X}=60)$. Sehingga dapat disimpulkan bahwa penerapan model pembelajaran kooperatif tipe scramble berbantuan bahan manipulatif berpengaruh terhadap kompetensi pengetahuan matematika siswa kelas IV SD Gugus Letkol Wisnu Denpasar Utara Tahun Pelajaran 2016/2017.

Penelitian ini menguji pengaruh model pembelajaran kooperatif tipe scramble berbantuan bahan manipulatif terhadap kompetensi pengetahuan matematika siswa Kelas IV SD Gugus Letkol Wisnu Denpasar Utara Tahun Pelajaran 2016/2017 pada materi hubungan antargaris. Sebelum dilakukan uji hipotesis statistik dengan menggunakan analisis uji-t, terlebih dahulu dilakukan uji prasyarat yang meliputi uji normalitas sebaran data dan uji homogenitas varians. Dari hasil perhitungan diketahui bahwa sebaran data hasil post-test pada kedua kelompok berdistribusi normal dan memiliki varians yang homogen. Karena data pada kelompok eksperimen dan kelompok kontrol telah memenuhi semua prasyarat, selanjutnya dilakukan analisis dengan menggunakan uji-t.

Rata-rata kompetensi pengetahuan matematika siswa kelompok eskperimen lebih dari rata-rata kompetensi pengetahuan matematika siswa kelompok kontrol $(\bar{X}=78,39>\bar{X}=60)$. Sehingga dapat disimpulkan bahwa penerapan model pembelajaran kooperatif tipe scramble berbantuan bahan manipulatif berpengaruh terhadap kompetensi pengetahuan matematika siswa kelas IV SD Gugus Letkol Wisnu Denpasar Utara Tahun Pelajaran 2016/2017.

Dari perolehan nilai kompetensi pengetahuan matematika pada kedua kelompok dapat diketahui bahwa kedua kelompok yang awalnya memiliki kemampuan setara, lalu setelah diberikan treatment yang berbeda perolehan nilai kompetensi pengetahuan matematika mengalami perbedaan. Kompetensi pengetahuan matematika siswa pada kelompok eksperimen lebih baik apabila dibandingkan dengan kompetensi pengetahuan matematika siswa pada kelompok kontrol. Hal ini disebabkan oleh pembelajaran yang diterapkan pada kelompok eksperimen memiliki banyak keunggulan.

Perbedaan yang signifikan kompetensi pengetahuan matematika kelompok eksperimen dan kelompok kontrol terjadi karena perbedaan pemberian treatment yang diberikan saat pembelajaran. Kelompok eksperimen diberikan pembelajaran dengan menerapkan model pembelajaran kooperatif tipe scramble berbantuan bahan manipulatif memiliki nilai rata-rata yang lebih tinggi dibandingkan dengan kelompok kontrol yang tidak menerapkan model pembelajaran kooperatif tipe scramble berbantuan bahan manipulatif.

Penerapan model pemebelajaran kooperatif tipe scramble berbantuan bahan manipulatif dapat meningkatkan faktor-faktor yang mempengaruhi kompetensi pengetahuan matematika. Minat belajar siswa dapat ditingkatkan melalui kegiatan menyusun kembali jawaban yang sudah diacak. Kegiatan ini membuat siswa merasa sedang bermain, yaitu bermain menyusun jawaban sehingga ketika pembelajaran berlangsung pada kelas eksperimen mereka terlihat bersemangat dan senang mengikuti pembelajaran. Interaksi siswa meningkat karena pada model ini siswa diberikan kesempatan untuk berdiskusi dan berinteraksi dengan temannya dalam menemukan dan memahami suatu konsep. Setiap anggota kelompok juga bertanggungjawab atas segala sesuatu yang dikerjakan dalam kelompoknya, sehingga setiap siswa tidak ada yang diam. Mereka bertanggungjawab akan keberhasilan kelompoknya. Mereka saling bekerjasama dalam menyusun jawaban. Selain itu, penggunaan media berupa bahan manipulatif dapat mempermudah siswa dalam memahami suatu konsep matematika. Materi yang semula dianggap sulit menjadi lebih mudah untuk dipahami.

Berbeda dengan pembelajaran matematika di kelompok kontrol yang tidak menerapkan model pembelajaran kooperatif tipe scramble berbantuan bahan manipulatif. Siswa pada kelompok kontrol terlihat tidak bersemangat dan kurang antusias dalam mengikuti pembelajaran yang tengah berlangsung. Proses pembelajaran yang kurang menyenangkan membuat siswa merasa bosan sehingga sulit untuk memahami materi pelajaran. 
Penelitian ini diperkuat oleh penelitian yang relevan, yang dilakukan Suryanta (2014) dengan hasil penelitian yakni model pembelajaran scramble berbantuan media gambar animasi berpengaruh terhadap hasil belajar IPA siswa kelas V semester I SD Gugus Yos Sudarso Sanur Denpasar Selatan Tahun Pelajaran 2013/2014.

Penelitian ini juga diperkuat oleh hasil penelitian Patricasari (2014) yang menyimpulkan bahwa penerapan pembelajaran PBI berbantuan bahan manipulatif berpengaruh terhadap hasil belajar matematika siswa kelas V SD Gugus Letda Kajeng Denpasar Utara tahun pelajaran 2013/2014.

\section{Simpulan dan Saran}

Hasil analisis uji $t$ diperoleh $t_{\text {hitung }}=7,27$. Harga tersebut kemudian dibandingkan dengan harga $t_{\text {tabel }}$ dengan $\mathrm{dk}=45+48-2=91$ dan taraf signifikansi 5\% sehingga diperoleh harga $\mathrm{t}_{\text {tabel }}=1,980$, karena $\mathrm{t}_{\text {hitung }}>\mathrm{t}_{\text {tabel }}$ maka Ho ditolak atau Ha diterima. Hal ini berarti terdapat perbedaan yang signifikan kompetensi pengetahuan matematika siswa yang dibelajarkan menggunakan model pembelajaran kooperatif tipe scramble berbantuan bahan manipulatif dan siswa yang tidak dibelajarkan menggunakan model pembelajaran kooperatif tipe scramble berbantuan bahan manipulatif pada kelas IV SD Gugus Letkol Wisnu Denpasar Utara Tahun Pelajaran 2016/2017.

Rata-rata kompetensi pengetahuan matematika siswa kelompok eskperimen lebih dari rata-rata kompetensi pengetahuan matematika siswa kelompok kontrol $(\bar{X}=78,39>\bar{X}=60)$. Sehingga dapat disimpulkan bahwa penerapan model pembelajaran kooperatif tipe scramble berbantuan bahan manipulatif berpengaruh terhadap kompetensi pengetahuan matematika siswa kelas IV SD Gugus Letkol Wisnu Denpasar Utara Tahun Pelajaran 2016/2017.

Berdasarkan hasil penelitian ini, saran yang dapat disampaikan adalah sebagai berikut. Kepada guru hendaknya dapat menambah wawasannya mengenai inovasi pembelajaran sehingga mampu menerapkan ataupun mengembangkan pembelajaran di kelas secara lebih inovatif dan bervariasi agar dapat memberikan dampak positif dalam meningkatkan kompetensi pengetahuan siswa. Salah satu model pembelajaran yang dapat diterapkan oleh guru dalam menciptakan pembelajaran yang menarik adalah model pembelajaran kooperatif tipe scramble berbantuan bahan manipulatif. Untuk lembaga sekolah hendaknya menyediakan sarana yang maksimal untuk menunjang pembelajaran agar siswa semakin termotivasi untuk belajar dan memanfaatkan sarana tersebut untuk mengoptimalkan kompetensi siswa sehingga mutu sekolah menjadi semakin meningkat.Kepada peneliti lain, diharapkan dapat melakukan penelitian lebih lanjut dengan menerapkan model pembelajaran kooperatif tipe scramble berbantuan bahan manipulatif. Pada materi pembelajaran yang berbeda atau dapat pula dilakukan penelitian lebih lanjut dengan menggunakan model pembelajaran kooperatif tipe scramble berbantuan bahan manipulatif pada sumber data/sampel yang berbeda khususnya pada muatan pembelajaran matematika sehingga hasil penelitian benar-benar dapat menggambarkan keadaan sesungguhnya yang terjadi di lapangan.

\section{Daftar Pustaka}

Huda. 2013. Model-Model Pengajaran dan Pembelajaran. Yogyakarta: Pustaka Belajar

Japa, I Gusti Ngurah dan I Made Suarjana. 2014. Pendidikan Matematika I. Singaraja: Universitas Pendidikan Ganesha

Japa, I Gusti Ngurah dan I Made Suarjana. 2015. Pendidikan Matematika III. Singaraja: Universitas Pendidikan Ganesha

Kurniasih, Imas dan Berlin Sari. 2016. Ragam Pengembangan Model Pembelajaran Untuk Peningkatan Profesionalitas Guru. Jakarta: Kata Pena

Muhsetyo. 2008. Pembelajaran Matematika SD. Jakarta: Univeritas Terbuka

Nazir. 2011. Metode Penelitian. Bogor: Ghalia Indonesia

Patricasari, Ni Putu Lisa Andreyani. 2014. "Pembelajaran Problem Based Instruction Berbantuan Bahan Manipulatif Berpengaruh terhadap Hasil Belajar Matematika Siswa Kelas V SD Gugus Letda Kajeng”. Jurnal Mimbar PGSD Universitas Pendidikan Ganesha, Vol: 2 No: 1

Permendikbud. 2014. Peraturan Menteri Pendidikan dan Kebudayaan Republik Indonesia Nomor 57 Tahun 2014 Tentang Kurikulum 2013 Sekolah Dasar/Madrasah Ibtidaiyah. Jakarta: Kementerian Pendidikan dan Kebudayaan.

Setyosari. 2015. Metode Penelitian Pendidikan dan Pengembangan. Jakarta: Prenadamedia Group

Sudijono, Anas. 2013. Pengantar Evaluasi Pendidikan. Jakarta: PT Raja Grafindo Persada

Sugiyono. 2014. Metode Penelitian Pendidikan Pendekatan Kuantitatif, Kualitatif dan R\&D. Bandung: Alfabeta.

Suharsimi. 2013. Dasar-dasar Evaluasi Pendidikan. Jakarta: Bumi Aksara. 
Suryanta, I Made. 2014. "Pengaruh Pengaruh Model Pembelajaran Scramble Berbantuan Media Gambar Animasi terhadap Hasil Belajar IPA Siswa Kelas V SD Gugus Yos Sudarso Denpasar”. Jurnal Mimbar PGSD Universitas Pendidikan Ganesha, Vol: 2 No: 1

Undang-Undang No. 20 Tahun 2003 tentang Sistem Pendidikan Nasional.Jakarta: Departemen Pendidikan Nasional

Yusuf, Muri. 2015. Asesmen dan Evaluasi Pendidikan. Jakarta: Prenadamedia Group 